\title{
Integrating Suspended Copper/Iron Bimetal Nanoparticles and Microwave Irradiation for Treating Chlorobenzene in Aqueous Solution
}

\author{
Chien-Li Lee ${ }^{1} \&$ Chih-Ju G Jou ${ }^{2}$ \\ ${ }^{1}$ Research and Development Center for Water Resource and Conservation, National Kaohsiung First University \\ of Science and Technology, Taiwan \\ ${ }^{2}$ Department of Safety, Health and Environmental Engineering, National Kaohsiung First University of Science \\ and Technology, Taiwan \\ Correspondence: Chih-Ju G. Jou, 2, Juoyue Road, Nantsu District, Kaohsiung 811, Taiwan. Tel: 886-7-601-1000 \\ ext. 2316. E-mail: george@ccms.nkfust.edu.tw
}

Received: January 9, 2012 Accepted: January 29, 2012 Online Published: June 20, 2012

doi:10.5539/ep.v1n2p159 URL: http://dx.doi.org/10.5539/ep.v1n2p159

\begin{abstract}
Microwave irradiation is combined with copper/iron bimetal $(\mathrm{Cu} / \mathrm{Fe})$ nano-particles suspended in aqueous chlorobenzene solution for reducing chlorobezene activation energy to enhance its decomposition. When the metal particles are suspended in solution, the total surface area to absorb the MW energy will increase so that the heat converted from the absorbed MW energy will be distributed evenly in the solution to enhance CB decomposition. Laboratory results show that when $250 \mathrm{~W}$ of microwave energy is applied for 300 sec to irradiate $100 \mathrm{mg} \mathrm{L}^{-1}$ of $\mathrm{CB}$ solution containing $1 \mathrm{~g}$ of suspended $\mathrm{Cu} / \mathrm{Fe}$ bimetallic particles, the $\mathrm{CB}$ removal rate is improved by 1.3 times $(95.0 \%$ vs. $76.2 \%)$, and the activation energy is lowered by 3 to $6 \%$. The integrated suspended copper/iron bimetal nano-particle and Microwave Irradiation system is confirmed to be an effective method to treat chlorobenzene.
\end{abstract}

Keywords: chlorobenzene, Microwave irradiation, copper-iron bimetal

\section{Introduction}

Studies conducted in recent years show that electrons generated by zero-valent iron ( $\mathrm{ZVI}$ or $\left.\mathrm{Fe}^{0}\right)$ are effective in dechlorating and treating organic chlorine-containing matter contained in wastewater or groundwater (Lin \& Lo, 2005; Clark II et al., 2003). For example, zero-valent iron was implemented successfully for treating various groundwater and soil contaminated by various organic contaminants, e.g., halogenated organics solvents, azoaromatics and nitroaromatics (Xu et al., 2005a, 2005b, 2006; Lien \& Zhang, 2007), and inorganic pollutants, e.g., arsenic, chromium and copper. The end products of zero-valent iron treatment are carbon hydrogen, chloride and ferric oxides, among the many others (Janda et al., 2004; Lin et al., 2004; Liou et al., 2005). Two major disadvantages are associated with the use of plain zero-valent iron nano-particles: 1) Iron oxides are easily formed on the nano-particle surface so that the particle surface reactivity is greatly reduce, and high iron surface activity is difficult to maintain; and 2) Irons of different sources may have various activities (Lin et al., 2004; Zhang et al., 1998). If zero-valent iron nano-particles are covered with a second metal, e.g. Pt, $\mathrm{Ag}, \mathrm{Ni}$ or $\mathrm{Cu}$, the metal-covered iron particles, or double metal catalyst, are more effective in treating chlorine-containing organic pollutants with faster reaction rate than zero-valent iron nano-particles alone (Lin et al., 2004). The advantages of metal-covered ZVI particles include: (1) effectively lowering the activation energy of the pollutants, increasing the reaction rate of de-chlorinaton reactions, and reducing the formation of secondary products (Liou et al., 2005), (2) alleviating the problem of forming oxides on the iron particle surface, and (3) rapidly releasing electrons from zero-valent iron nano-particles (Cheng \& Wu, 2000). Additionally, the process of using the double-metal catalyst requires relatively simple equipment to achieve rapid and complete dechlorination (Lien and Zhang, 2007) by increasing the iron particle surface area, and surface activity to reduce the formation of byproducts (Clark II et al., 2003; Zhang et al., 1998).

Microwave (MW) is a multiple frequency $(300 \mathrm{MHz}$ to $600 \mathrm{MHz}$ ) electro-magnetic radiation (Jones et al., 2002; Appleton et al., 2005; Yuan et al., 2006), it induces dipole orientation (dipole rotation) and ionic conduction to 
generate internal heat in the media irradiated (Hidaka et al., 2007), and also reduces the solution activation energy by weakening chemical bonds (Zhang et al., 2007). Recently, the microwave heating technology has attracted much interest in various fields because of the rapid homogeneous heating that is capable of enhancing reaction kinetics (Menéndez et al., 2002; Park et al., 2002; Takashima et al., 2008). The microwave is also combined with granular activated carbon or zero-valent iron nano-particles for treating pentachlorophenol (Jou, 2008; Jou \& Wu, 2008; Lee et al., 2010a ), chlorobenzene (Lee et al., 2009a, 2010b; Jou et al., 2010a, 2010b) and improving the efficiency of $\mathrm{TiO}_{2}$ photocatalyst (Jou et al., 2008) for savings energy while improving efficiencies (Liu et al., 2004). In this study, the unique characteristics of nano-scale bi-metal catalysts, e.g. enhanced surface area and reactivity, and the rapid heating of microwave are combined into a new integrated method for treating aqueous chlorobenzene solution. The bimetal particles will absorb microwave energy within the particles. When they are suspended throughout chlorobenzene solution and irradiated with microwave, each nano-particles will produce heat so that the heat is more rapidly produced and evenly distributed throughout the bulk of the chlorobenzene solution. The influence of microwave irradiation on reducing chlorobenzend activation energy and increasing the removal efficiency is investigated.

\section{Materials and Methods}

\subsection{Reagent}

The chlorobenzene solution was prepared by dissolving $905 \mu \mathrm{L}$ of chlorobenzene $(99.9 \%$ purity GR Reagent, TEDIA, USA) in methanol (99.9\% purity, GR Reagent, TEDIA, USA) with the final concentration of the stock solution adjusted to $20000 \mathrm{mg} \mathrm{L}^{-1}$. When needed, $250 \mu \mathrm{L}$ of the stock solution was dissolved in de-ionized water (18.2 M $\Omega$, Millipore Co, USA) with the final volume adjusted to yield $100 \mathrm{mg} \mathrm{L}^{-1}$ chlorobenzene.

\subsection{Preparation of $\mathrm{Cu} / \mathrm{Fe}$ Bimetal Nano-particles}

Raw $\mathrm{Fe}^{0}$ and $\mathrm{Cu}^{0}$ nano-particles were purchased from Conyuan Biochemical Technology Ltd. The $\mathrm{Cu} / \mathrm{Fe}$ bimetal particles were produced using the wet reduction method by adding $1 \mathrm{~g}$ zero-valent iron nano-particles to each of 5 test tubes containing $5,10,50$, and $100 \mathrm{~mL}$ of $1000 \mathrm{mg} \mathrm{L}^{-1}$ copper dichloride solution. The $\mathrm{Cu}^{+2}$ ions rapidly convert to $\mathrm{Cu}^{0}$ to release ferric ions; the converted $\mathrm{Cu}^{0}$ deposits on the surface of zero-valent iron nano-particles. Completion of the reaction is seen by the solution color changing from the original blue to light yellow. Nearly all $\mathrm{Cu}^{+2}$ ions are converted to $\mathrm{Cu}^{0}$ to deposit on the zero-valent iron nano-particle surface although a tiny quantity of $\mathrm{Cu}^{+2}$ remains in the solute due to chemical equilibrium. Subsequently, the $\mathrm{Cu}^{0}$ coated zero-valent iron nano-particles $(\mathrm{Cu} / \mathrm{Fe}$ bi-metal particles) are separated from the liquid; ratios of $\mathrm{Cu} / \mathrm{Fe}$ are $0.5,1,5$ and $10 \%$ of $\mathrm{Cu} / \mathrm{Fe}(\mathrm{w} / \mathrm{w})$ with the reduced element copper $\left(\mathrm{Cu}^{0}\right)$ lodged in the surface structure of the iron particles. Specific surface areas of nano-scale $\mathrm{Fe}^{0}, \mathrm{Cu}^{0}$ and $\mathrm{Cu} / \mathrm{Fe}$ particles are 55.8, 44.8 and $43.43 \mathrm{~m}^{2} \mathrm{~g}^{-1}$, respectively, as measured using a BET surface analyzer.

\subsection{Experimental Methods}

The study was carried out using $40 \mathrm{~mL}$ of $100 \mathrm{mg} \mathrm{L}^{-1} \mathrm{CB}$ solution placed in 3 sets of boron-silica glass column reactors. Three sets of reactor containing chlorobenzene aqueous solution were added with $1 \mathrm{~g}$ of $\mathrm{Fe}^{0}, \mathrm{Cu}^{0}$ and $\mathrm{Cu} / \mathrm{Fe}$ nano-particles, respectively. The $\mathrm{CB}$ decomposition study was carried out at various constant temperatures for 30, 60, 120, 150, 180, 210 and $240 \mathrm{~min}$.

For the microwave irradiation study, a $2.45 \mathrm{GHz}$ microwave with a max power of $650 \mathrm{~W}$ was used to generate microwave energy. An $80-\mathrm{mL}$ boron-silica glass column reactor that is made of low-energy-loss and heat-resistant was used to hold the sample; the reactor was placed in the microwave oven for carrying out the MW irradiation experiment. The top of the reactor was connected to a vacuum gas collecting bag for capturing all organic substances that may escape with the tail gas during the reaction period. Constant microwave energy of $250 \mathrm{~W}$ was used to irradiate CB samples for $20 \mathrm{sec}$ followed by interruption of no irradiation for $120 \mathrm{sec}$ as one cycle; the experiment was repeated for 15 cycles. Triplicate samples were used in all studies; the average was used to calculate the $\mathrm{CB}$ removal efficiency.

\subsection{Analyses}

Chemical analyses of organic intermediates and final products matter was performed with HP 6890 gas chromatography (GC) using the HP-5MS capillary column; the chromatography is equipped with an HP 5973 mass selective detector (MSD). The constant carrying gas (He) flow rate was maintained at $1.5 \mathrm{~mL} \mathrm{~min}^{-1}$. The oven temperature was programmed to vary from $70{ }^{\circ} \mathrm{C}$ to $260{ }^{\circ} \mathrm{C}$ at an increasing rate of $30^{\circ} \mathrm{C} \mathrm{min}^{-1}$ to remain at $260{ }^{\circ} \mathrm{C}$ for 5 more min. Changes of nano-particle surface were detected using Scanning Electron microscopic (Hitachi, S-2500) images. Samples were scanned with Fourier Transformation Infra Red (FTIR, NICOLET-is10) using $\mathrm{KBr}$ window between 400 to $4000 \mathrm{~cm}^{-1}$ for 8 times to result in images with 0.5 resolution. 


\section{Results and Discussion}

\subsection{The Optimal Quantity of $\mathrm{Cu}$ Deposited}

Deposition of copper on the iron particle surface will generate numerous localized galvanic cells that promote the iron corrosion to facilitate release of electrons (Lin et al., 2004; Lien \& Zhang, 2001), and favor the thermodynamic reactions $(\Delta \mathrm{E} 0=+0.784 \mathrm{~V})$ (Eq. 1 3).

$$
\begin{array}{rl}
\mathrm{Fe}^{0} \rightarrow \mathrm{Fe}^{2+}+2 \mathrm{e}^{-} & \mathrm{E}=0.447 \mathrm{~V} \\
+\mathrm{Cu}^{2+}+2 \mathrm{e}^{-} \rightarrow \mathrm{Cu}^{0} & \mathrm{E}=0.337 \mathrm{~V} \\
\mathrm{Fe}^{0}+\mathrm{Cu}^{2+} \rightarrow \mathrm{Fe}^{2+}+\mathrm{Cu}^{0} & \mathrm{E}=0.784 \mathrm{~V}
\end{array}
$$

The data obtained on $100 \mathrm{mg} \mathrm{L}^{-1} \mathrm{CB}$ solution treated with $0.5,1,5$, and $10 \%$ of $1 \mathrm{~g} \mathrm{Cu} / \mathrm{Fe}$ particles without microwave irradiation are shown in Figure 1 and Figure 2. Laboratory results indicates that at room temperature $\left(25^{\circ} \mathrm{C}\right)$, the chlorobenzene reaction rate constants after $240 \mathrm{~min}$ are $1.4 \times 10^{-3} \mathrm{~min}^{-1}$ for $0.5 \%$ of $\mathrm{Cu} / \mathrm{Fe}(\mathrm{w} / \mathrm{w}), 1.8$ $\times 10^{-3} \mathrm{~min}^{-1}$ for $1 \%$ of $\mathrm{Cu} / \mathrm{Fe}(\mathrm{w} / \mathrm{w}), 3.4 \times 10^{-3} \mathrm{~min}^{-1}$ for $5 \%$ of $\mathrm{Cu} / \mathrm{Fe}(\mathrm{w} / \mathrm{w})$, and $1.5 \times 10^{-3} \mathrm{~min}^{-1}$ for $10 \%$ of $\mathrm{Cu} / \mathrm{Fe}(\mathrm{w} / \mathrm{w})$ with removal efficiency of $27.9 \%, 36.8 \%, 62.0 \%$ and $32.7 \%$, respectively. The iron nano-particles with various quantities of $\mathrm{Cu}$ deposited show different reaction rates and efficiencies of $\mathrm{CB}$ removal. When the quantity of $\mathrm{Cu}$ deposited is smaller than $5 \%$, both reaction rate constant and $\mathrm{CB}$ removal efficiency increase with higher $\mathrm{Cu}$ deposited until the optimum $5 \%$ level of $\mathrm{Cu}$ deposit is reached. If the quantity of $\mathrm{Cu}$ deposited exceeds $5 \%$ the efficiency will not be further enhanced or even reduced. Results of t-test carried out on curves plotted in Figure 2 confirm that the 5\% Cu deposit curve is much better than all other curves for $0.5 \%, 1 \%$ and $10 \%$ of $\mathrm{Cu}$ deposits. These observations are similar to those made by Liou et al. (2005) when using nano-scale $\mathrm{Cu} / \mathrm{Fe}$ particles to carry out the reduction of nitrate. They reported that the $\mathrm{Cu} / \mathrm{Fe}(\mathrm{w} / \mathrm{w})$ of $5 \%$ has the optimum removal efficiency whereas $\mathrm{Cu} / \mathrm{Fe}(\mathrm{w} / \mathrm{w})$ exceeding $5 \%$ will not further enhance the removal efficiency. In another study using the $\mathrm{Ru} / \mathrm{Fe}$ bi-metal to decompose Trichloroethylene, Lin et al. (2005) observed that the quantity of Ru deposited greater than $1.5 \%$ will cause higher reaction rate constants with increasing quantity of $\mathrm{Ru}$ deposited until $5 \%$ of $\mathrm{Ru}$ deposit is reached. Their results seem to be somehow comparable with the observations made in this study.

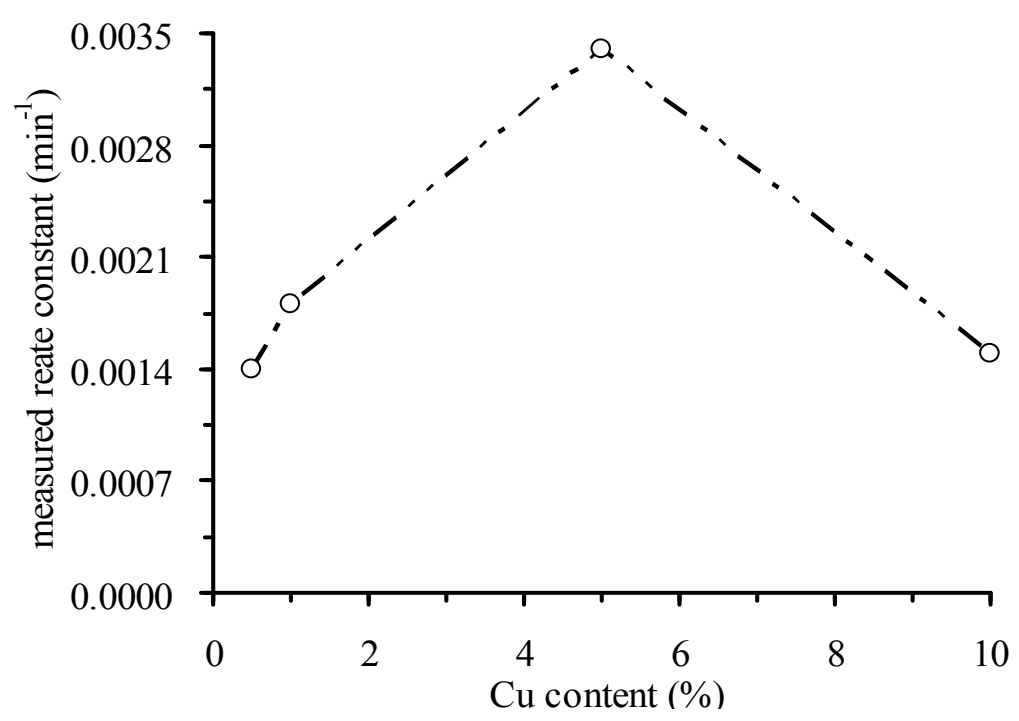

Figure 1. Relationship between the $\mathrm{Cu}$ content in the $\mathrm{Cu} / \mathrm{Fe}$ bi-metal nanoparticles and the measured reaction rate constant

The XRD of X-ray diffraction of the nano-scale bi-metal particles shows that obvious peaks occur at $2 \theta$ of 44.9 and $65.2 \mathrm{Cu} / \mathrm{Fe}$ (Figure 3a) indicating the existence of crystal zero-valent iron at $2 \theta$ of 35.9 and 44.9 (Figure 3b). 


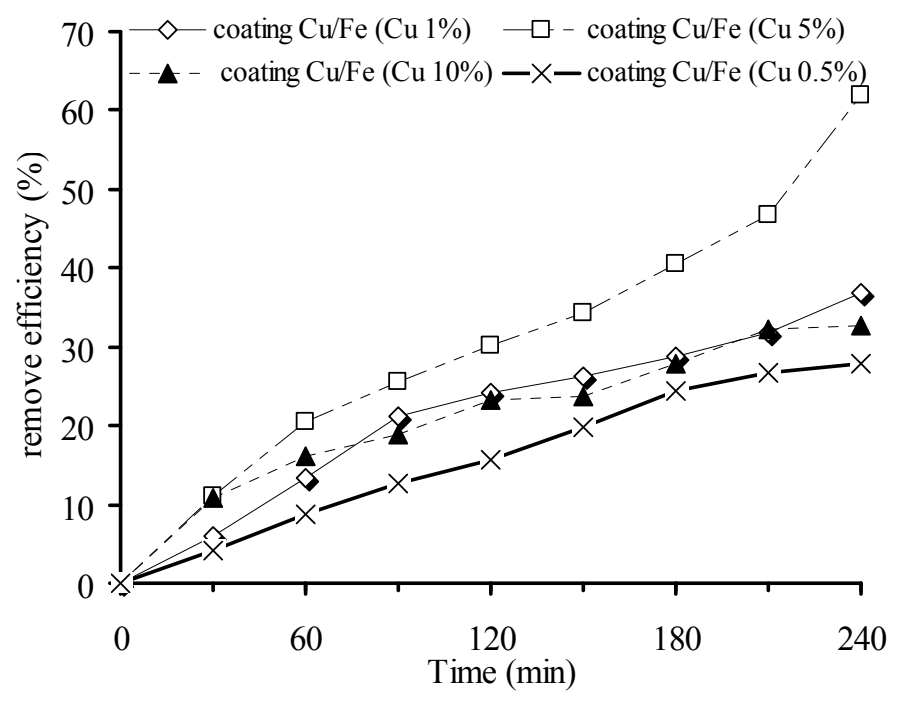

Figure 2. Chlorobenzene removal efficiencies for the $\mathrm{Cu} / \mathrm{Fe}$ bi-metal nanoparticles containing various $\mathrm{Cu}$ Content at different reaction times (without microwave irradiation)
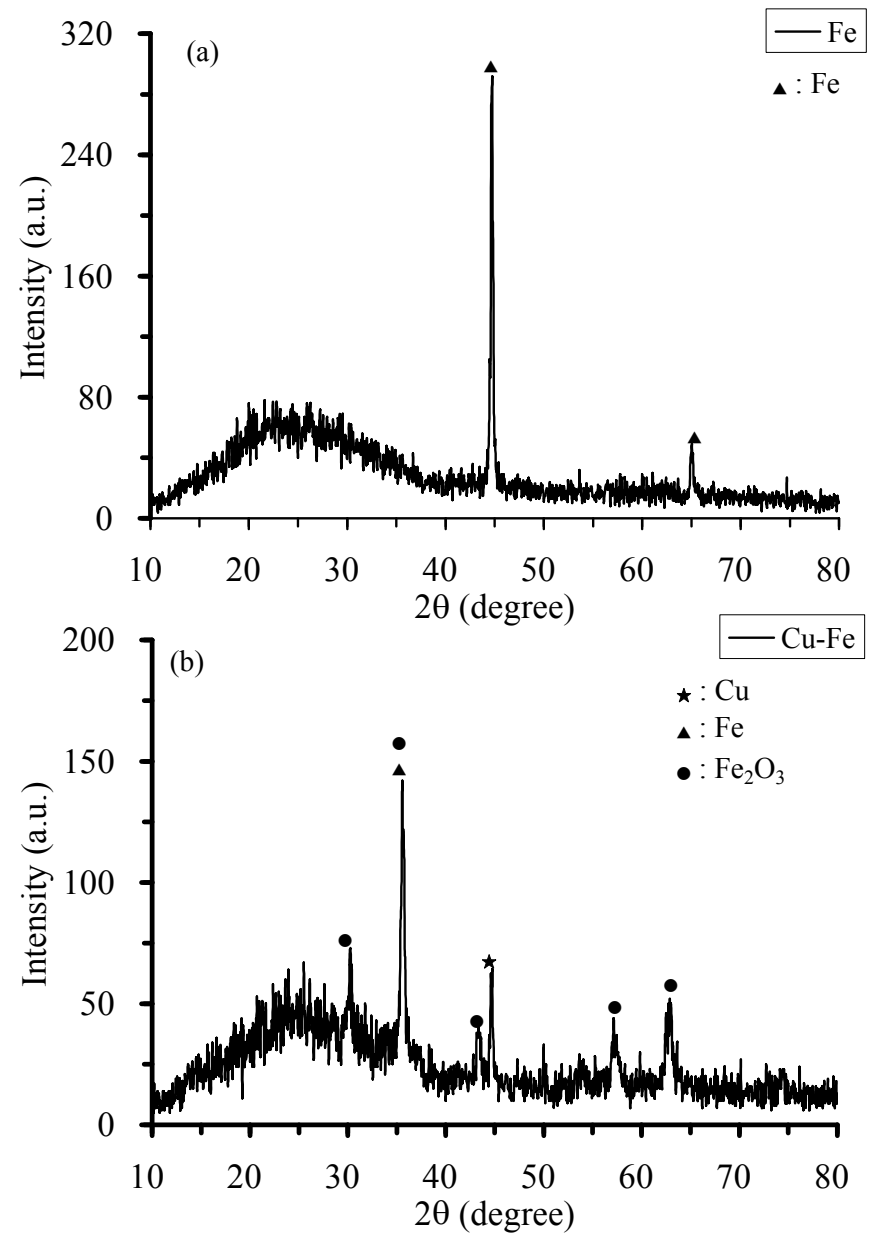

Figure 3. $\mathrm{Cu} / \mathrm{Fe}(\mathrm{w} / \mathrm{w})=0.5 \%$ and $\mathrm{Fe} \mathrm{XRD}$

\subsection{CB Degradation for Nano-scale Particles of $\mathrm{Cu} / \mathrm{Fe}, \mathrm{Fe}^{0}$ and $\mathrm{Cu}^{0}$}

Copper has a small electropotential than iron; when copper is deposited on the surface of nano-scale $\mathrm{Fe}^{0}$ particles $(\mathrm{Cu} / \mathrm{Fe}$ bi-metal particles), the electropotential difference between these two metals causes the release of 
electrons to enhance the corrosion and reactivity of $\mathrm{Fe}^{0}$ particles. Comparison of the $\mathrm{CB}$ decomposition rates using nano-scale particles of $\mathrm{Cu} / \mathrm{Fe}$ bi-metal, zero-valent $\mathrm{Fe}$, and zero-valent copper with microwave irradiation are shown in Figure 4. Results of t-test confirm that the $5 \% \mathrm{Cu} / \mathrm{Fe}$ curve is obviously different from those for $0.5 \%, 1 \%$ and $10 \% \mathrm{Cu} / \mathrm{Fe}$ curves. When the $\mathrm{Cu} / \mathrm{Fe}(\mathrm{w} / \mathrm{w})$ ratio is $5 \%$ in the bi-metal particle, the $\mathrm{CB}$ removal efficiency is $62.0 \%$ whereas using $\mathrm{Fe}^{0}$ and $\mathrm{Cu}^{0}$ removes only $18.1 \%$, and $19.5 \%$ of $\mathrm{CB}$, respectively. A metal with lower hydrogen over-voltage $\left(\mathrm{Fe}^{0}\right)$ will be more easily oxidized than the metal with higher hydrogen over-voltage $\left(\mathrm{Cu}^{0}\right)$ that stays mostly in element form. The metal oxidation releases hydrogen in atomic form, which favors the reduction of organic matter ( $\mathrm{Su} \&$ Puls, 1999). The observed slightly higher CB removal efficiency for $\mathrm{Cu}^{0}$ than $\mathrm{Fe}^{0}(19.5 \mathrm{vs} .18 .1 \%)$ is caused by a higher hydrogen over-voltage for $\mathrm{Cu}^{0}(0.584 \mathrm{~V})$ than $\mathrm{Fe}^{0}(0.557 \mathrm{~V})$. The results also show a significant improvement of $\mathrm{CB}$ removal with the nano-scale $\mathrm{Cu} / \mathrm{Fe}$ paraticles (62.0 vs. $19.5 \%$ or $18.1 \%$ ). The major functions of $\mathrm{Cu}^{0}$ deposited on the surface of nano-scale $\mathrm{Fe}^{0}$ particles are: (1) catalytically accelerating the $\mathrm{CB}$ dechloration rate, (2) preventing the oxidizing membrane from forming on the surface of $\mathrm{Fe}^{0}$ particles and retention the reactivity of $\mathrm{Fe}^{0}$ particles, (3) enhancing $\mathrm{CB}$ reduction by rapid release of electrons due to the electropotential difference between of $\mathrm{Fe}^{0}$ and of $\mathrm{Cu}^{0}$ ( $\mathrm{Su}$ and Puls, 1999).

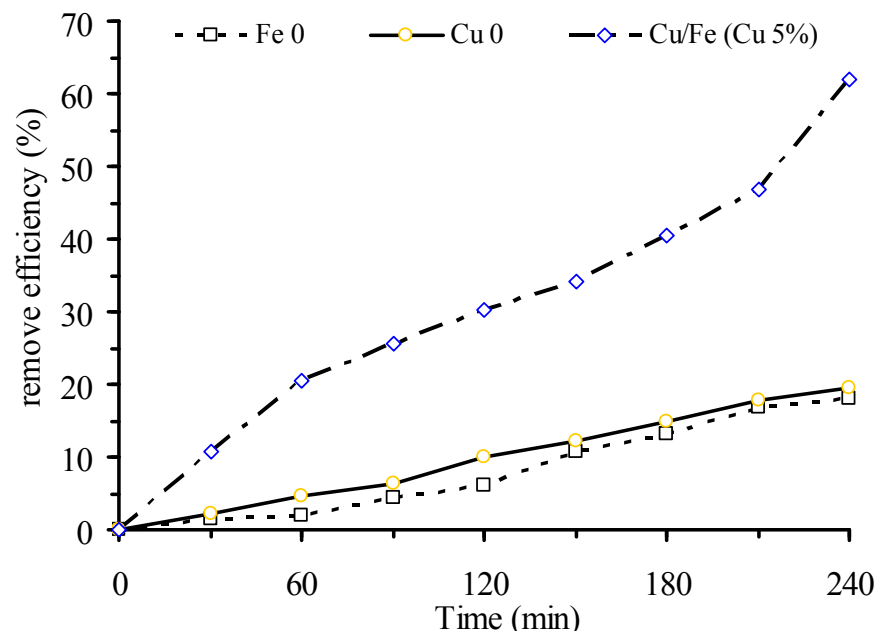

Figure 4. Comparison of chlorobenzene removal efficiencies for the nano-scale $\mathrm{Cu} / \mathrm{Fe}, \mathrm{Fe}^{0}$, and $\mathrm{Cu}^{0}$ particles at various treatment times (without microwave irradiation)

\subsection{Activation Energy of $\mathrm{CB}$ Degradation by Using $\mathrm{Cu} / \mathrm{Fe}, \mathrm{Fe}^{0}$ and $\mathrm{Cu}^{0}$}

For heterogeneous reactions, the effect of temperature on reaction rates reveals whether the rate-limiting step is to due chemical reactions at the surface, or the diffusion of the reactant in question (Lien \& Zhang, 2001) because a slower reaction step requires more activation energy (Ea). Lower Ea values are usually associated with the rate-limiting step that is a reactant diffusion, or diffusion-controlled process. Higher Ea values show that the process is chemical-controlled ( $\mathrm{Su}$ and Puls, 1999). The activation energies for diffusion-controlled reactions in solution are generally between $10-20 \mathrm{~kJ} / \mathrm{mol}$ (Liou et al., 2005). Rates of $\mathrm{CB}$ degradation with $\mathrm{Cu} / \mathrm{Fe}, \mathrm{Fe}^{0}$ and $\mathrm{Cu}^{0}$ particles at various temperatures are well fitted with linear plot of the Arrhenius equation expressed as ( $\mathrm{Su} \&$ Puls, 1999):

$$
\operatorname{lnksa}=\ln \mathrm{A}-\mathrm{Ea} / \mathrm{RT}
$$

Where: lnksa is the observed rate constant $\left(\mathrm{h}^{-1}\right)$; Ea is activation energy $\left(\mathrm{kJ} \mathrm{mol}^{-1}\right) ; \mathrm{R}$ is the molar gas constant $\left(8.314 \mathrm{~J} \mathrm{~mol}^{-1} \mathrm{~K}^{-1}\right)$; $\mathrm{T}$ is the absolute temperature $(\mathrm{K})$; and $\mathrm{A}$ is a pre-exponential factor $\left(\mathrm{L} \mathrm{h}^{-1} \cdot \mathrm{m}^{-2}\right)$. Therefore, straight lines are obtained when lnk is plotted versus $1 / \mathrm{T}$; the slope is the negative ratio of the activation energy to the ideal gas constant $(-\mathrm{Ea} / \mathrm{R})$, and the $\mathrm{y}$-axis intercept is $\ln \mathrm{A}$. Figure 5 gives the Arrhenius plots of ln ksa versus $1 / \mathrm{T}$ for the $\mathrm{CB}$ dechlorination with $\mathrm{Cu} / \mathrm{Fe}, \mathrm{Fe}^{0}$ and $\mathrm{Cu}^{0}$ nano-particles. The Arrhenius behavior is seen by the linear plot for the temperature range $25,40,50$ and $60{ }^{\circ} \mathrm{C}$, and the the activation energies of dechlorination degradation are $9.8 \mathrm{~kJ} / \mathrm{mol}$ for $\mathrm{Cu} / \mathrm{Fe}, 21.9 \mathrm{~kJ} / \mathrm{mol}$ for $\mathrm{Fe}^{0}$ nano-particles and $21.4 \mathrm{~kJ} / \mathrm{mol}$ for $\mathrm{Cu}^{0}$ nano-particles. For $\mathrm{Cu} / \mathrm{Fe}$ bi-metal particles, the reduction of $\mathrm{CB}$ activated energy is lower than $20 \mathrm{~kJ} / \mathrm{mol}$. This indicates that the rate-limiting step of $\mathrm{CB}$ degradation reaction begins to shift from surface reaction to mass transfer whereas the $\mathrm{CB}$ degradation limiting steps for both $\mathrm{Cu}^{0}$ and $\mathrm{Fe}^{0}$ are typical surface reaction. 


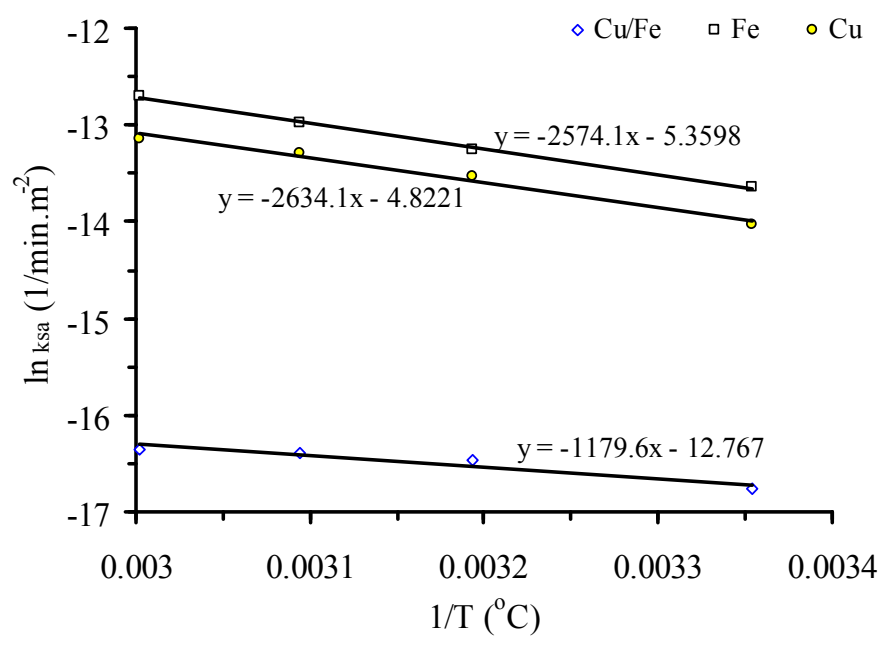

Figure 5. Linear plots of $\operatorname{lnk}_{\mathrm{sa}}$ vs. 1/T for chlorobenzene degradation using $\mathrm{Cu} / \mathrm{Fe}$ bimetal particles ( $\square$ solid line), $\mathrm{Fe}^{0}$ particles ( $\square$ solid line), and $\mathrm{Cu}^{0}$ particles ( $\circ$ solid line) particles at $25^{\circ} \mathrm{C}, 40^{\circ} \mathrm{C}, 50^{\circ} \mathrm{C}$ and $60^{\circ} \mathrm{C}$

\subsection{Effect of MW Radiation on CB Degradation by Using $\mathrm{Cu} / \mathrm{Fe}, \mathrm{Fe}^{0}$ and $\mathrm{Cu}^{0}$ as $\mathrm{MW}$ Absorbing Media}

MW irradiation will induce ion migration and dipole rotation causing the polar molecules in the solution to vibrate thus producing heat to raise the solution temperature (Lien and Zhang, 2007; Parida and Parija, 2006; Horikoshi and Serpone, 2009). The heat changes the thermodynamics characteristics as well; it reduces the activation energy of the reaction system, and weakens the molecular chemical bonds of the various substances in the solution. The existence of MW absorbing dielectric media will enhance the MW absorption to augment the influence of microwave on the degradation of solutes in the solution (Menéndez et al., 2002). The experiment on the influence of MW irradiation on $\mathrm{CB}$ degradation with $\mathrm{Fe}^{0}, \mathrm{Cu}^{0}$ and $\mathrm{Cu} / \mathrm{Fe}$ added to $\mathrm{CB}$ solution as $\mathrm{MW}$ absorbing media was carried out by fixing the MW output at $250 \mathrm{~W}$ for a total irradiation time of $300 \mathrm{sec}$. The results shown in Figure 6 reveal that when exposed to MW radiation, the $\mathrm{Cu} / \mathrm{Fe}$ bi-metal particles have better $\mathrm{CB}$ removal efficiency than either $\mathrm{Cu}^{0}$ or $\mathrm{Fe}^{0}$ particles during the first $80 \mathrm{sec}$. of total treatment time. This reveals that $\mathrm{Cu}^{0}$ molecules added to the zero-valent $\mathrm{Fe}^{0}$ particles behave as a catalyst to raise the $\mathrm{CB}$ removal efficiency. On the other hand, a substance that has more dielectric loss is better capable of converting MW energy into heat energy (Bilbao-Sáinz et al., 2007). The magnitude of dielectric loss is 38.2 for nano-scale $\mathrm{Fe}^{0}$ particles, 30 for $\mathrm{Cu} / \mathrm{Fe}$ particles and 9.7 for nano-scale $\mathrm{Cu}^{0}$ particles; hence, the order of the capacity to absorb MW and convert it into heat energy is $\mathrm{Fe}^{0}>\mathrm{Cu} / \mathrm{Fe}>\mathrm{Cu}^{0}$. The same order is reflected by the results shown in Figure 6 that under similar MW irradiation, the $\mathrm{CB}$ removal efficiency is $82.8 \%$ for $\mathrm{Fe}^{0}, 76.2 \%$ for $\mathrm{Cu} / \mathrm{Fe}$ and $72.1 \%$ for $\mathrm{Cu}^{0}$.

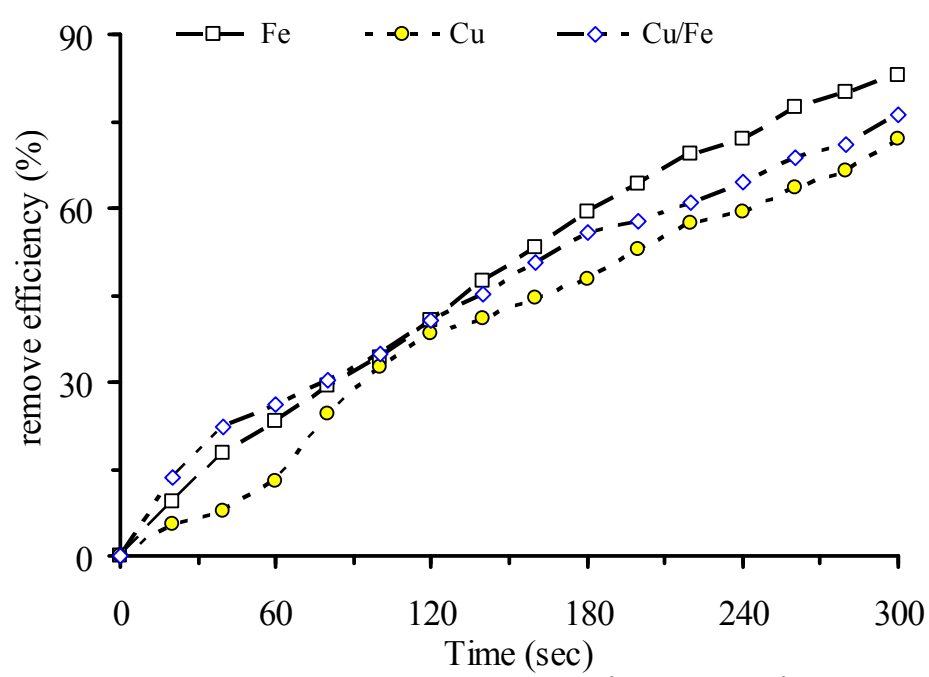

Figure 6. Chlorobenzene removal efficiencies for $\mathrm{Cu} / \mathrm{Fe}(\diamond), \mathrm{Fe}^{0}(\square)$ and $\mathrm{Cu}^{0}(\circ)$ particles (with microwave irradiation) 
Changes of the particle surface before and after CB decomposition have been observed with scanning electron microscope (SEM). As shown in Figure 7 (a) and (b), the appearance of $\mathrm{Fe}^{0}$ particles do not show obvious changes except that the microwave irradiated $\mathrm{Fe}^{0}$ nano-particles appear not as dense as they were before the irradiation. Figures 7 (c), (d), (e), and (f) show the same observations for $\mathrm{Cu}^{0}$ and $\mathrm{Cu} / \mathrm{Fe}$ particles.

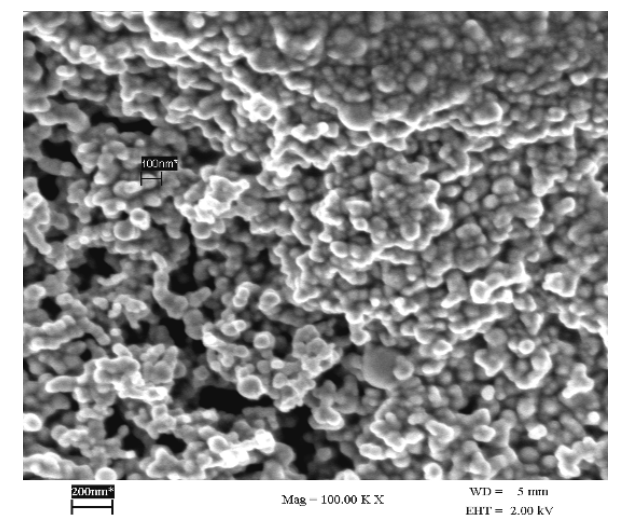

(a) Virgin $\mathrm{Fe}^{0}$

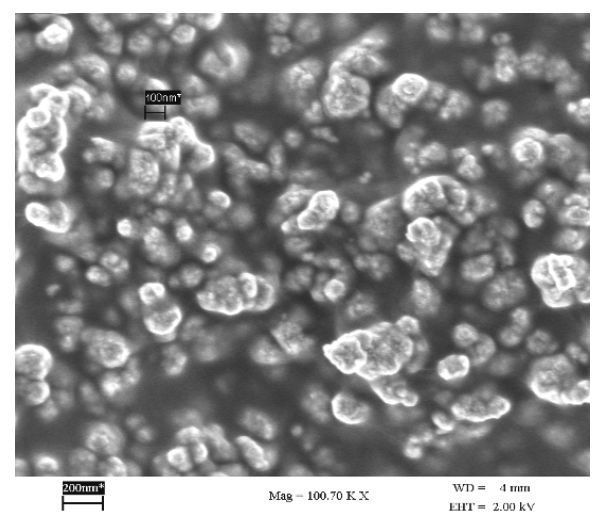

(c) Virgin $\mathrm{Cu}^{0}$

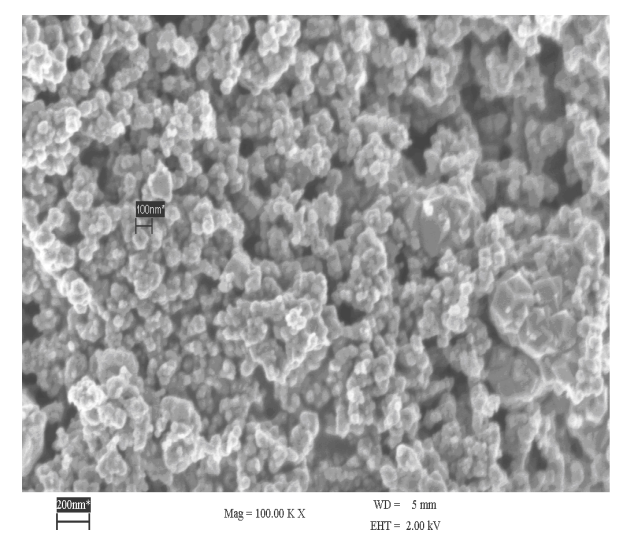

(e) Virgin $\mathrm{Cu} / \mathrm{Fe}$

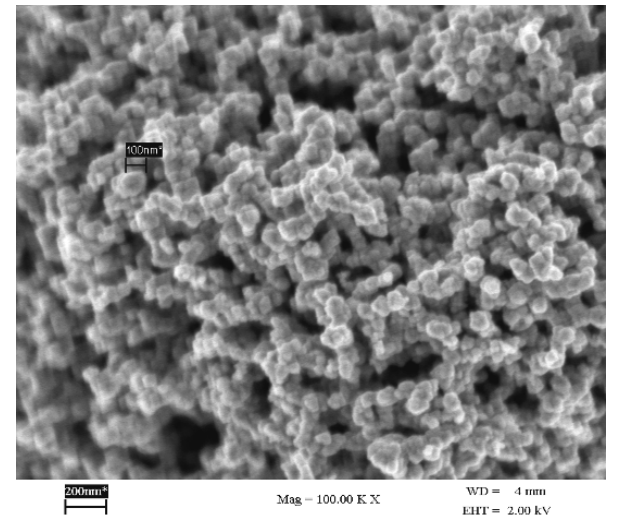

(b) $\mathrm{Fe}^{0}$ subject to microwave

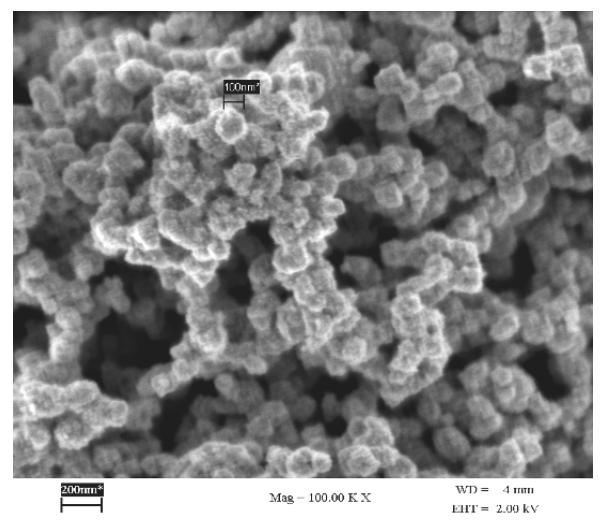

(d) $\mathrm{Cu}^{0}$ subject to microwave

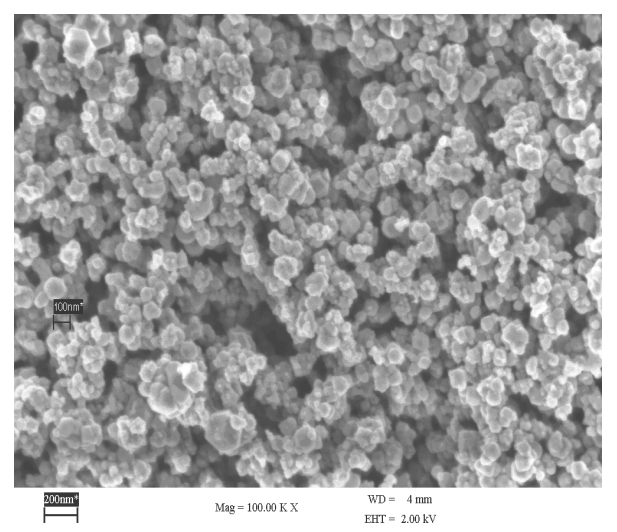

(f) $\mathrm{Cu} / \mathrm{Fe}$ subject to microwave

Figure 7. SEM images (Mag $=100 \mathrm{KX}$ ) showing changes of surface structure for $\mathrm{Fe}^{0}$ and $\mathrm{Cu}^{0}$ before and after being used as the medium in the microwave ( $250 \mathrm{~W}$ MW energy for $300 \mathrm{sec}$ ) treatment for chlorobenzene

\subsection{Suspension of $\mathrm{Cu} / \mathrm{Fe}$ in $\mathrm{CB}$ Solution}

The suspension of $\mathrm{Cu} / \mathrm{Fe}$ particles in $\mathrm{CB}$ solution will result in relatively larger $\mathrm{Cu} / \mathrm{Fe}$ particle surface area to absorb more microwave energy for generating more heat evenly distributed in the solution. Additionally, based on the principle of "non-thermal activation", the microwave energy will behave as the vibrating energy to agitate 
or align CB molecules so that the CB molecule activation energy is significantly reduced (Al- Harahsheh et al., 2006). When irradiated by microwave energy, $\mathrm{Cu} / \mathrm{Fe}$ particles absorb the $\mathrm{MW}$ energy that reaches the particle surface. The large particle surface area enhances the oxidation rate, and increases the active sites on the particle surface; the vigorous reaction re-suspends the particles that have settled to the bottom until all $\mathrm{Cu} / \mathrm{Fe}$ particles are fluidized in the solution. The $\mathrm{Cu} / \mathrm{Fe}$ particles thus suspended in $\mathrm{CB}$ solution will provide more solid/liquid contact area, absorb more MW energy, enhance $\mathrm{CB}$ degradation rate, and raise $\mathrm{CB}$ removal efficiency. Figure 8 shows that the suspended $\mathrm{Cu} / \mathrm{Fe}$ particles reduce the $\mathrm{CB}$ activation energy from 13.9 to $13.4 \mathrm{~kJ} \mathrm{~mol}^{-1}$, and remove $18.8 \%$ more $\mathrm{CB}(95.0 \%$ vs. $76.2 \%)$ than un-fluidized $\mathrm{Cu} / \mathrm{Fe}$ particle. The difference between these two curves is confirmed by the t-test results.

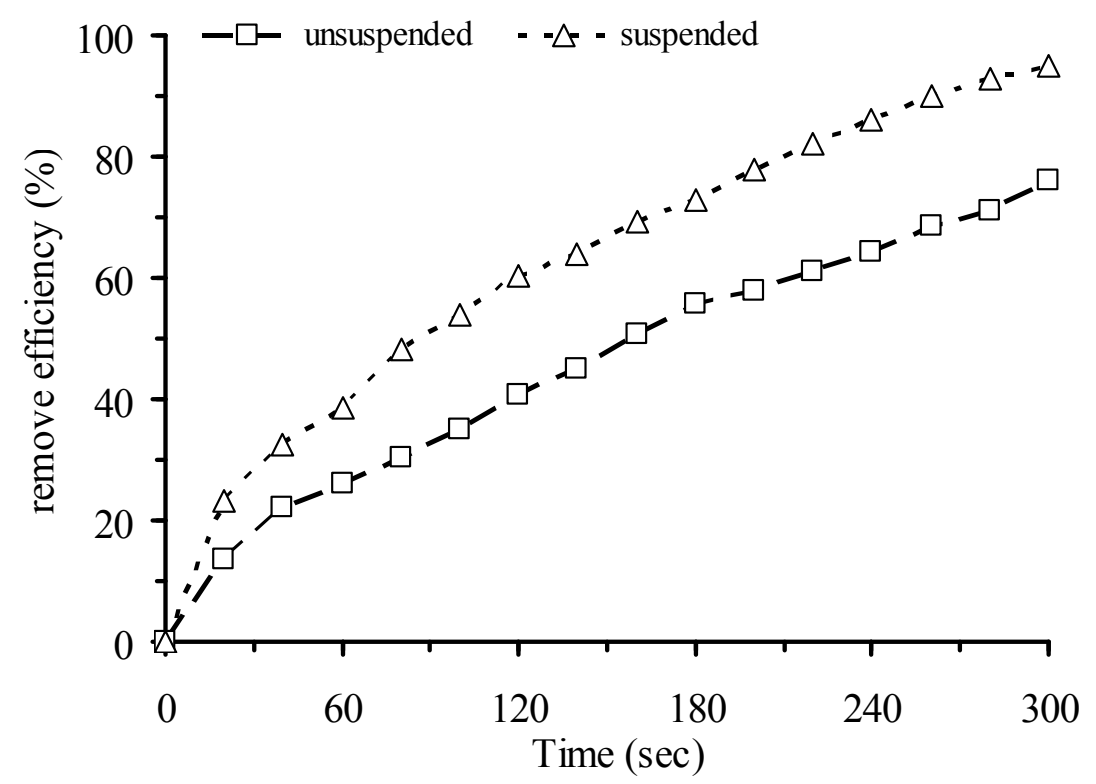

Figure 8. Enhanced chlorobenzene removal efficiency achieved by suspended $\mathrm{Cu} / \mathrm{Fe}$ particles (with microwave irradiation)

\subsection{Analyses of End-products}

Samples of the tail gas generated when the $\mathrm{CB}$ solution suspended with $\mathrm{Cu} / \mathrm{Fe}$ particles is irradiated using $250 \mathrm{~W}$ for $300 \mathrm{sec}$ are collected and analyzed using GC/MSD. Results of qualitative analyses indicate the presence of benzene compounds. The samples are further subject to FTIR (Fourier Transform Infrared) analyses to identify the end product. The results shows a major peak is seen to occur between $2320 \sim 2380 \mathrm{~cm}^{-1}$; other minor peaks obviously occur between $665 \sim 670,3598 \sim 3630$, and $3703 \sim 3730 \mathrm{~cm}^{-1}$, and hence $\mathrm{CO}_{2}$ is identified to be the major end product. Relatively wider absorbing peaks are also observed 1030 1032 $\mathrm{cm}^{-1}, 1340 \sim 1455 \mathrm{~cm}^{-1}, 2708 \sim 3060$ $\mathrm{cm}^{-1}$ and $3730 \sim 3833 \mathrm{~cm}^{-1} ; \mathrm{CH}_{3} \mathrm{OH}$ that comes from the solvent used to prepare $\mathrm{CB}$ solution is identified. Additionally, the strong absorbance in $1375 \sim 1875 \mathrm{~cm}^{-1}$ and $3600 \sim 3925 \mathrm{~cm}^{-1}$ indicate the presence of water originated from the aqueous solution. The chloride ion concentration in the treated chlorobenzene solution, measured with a chloride electrode, increases from 2.9 to $6.2 \mathrm{ppm}$, and the solution $\mathrm{pH}$ increases from 6.8 to 8.2

\section{Conclusion}

Embedding copper in the surface structure of nano-scale $\mathrm{Fe}^{0}$ particles will favor the iron oxidation to release electrons under the influence of different electropotentials of $\mathrm{Fe}^{0}$ and the embedded copper. Under similar experimental conditions, i.e. $25^{\circ} \mathrm{C}$ and 240 minute reaction time, the order of $\mathrm{CB}$ removal efficiencies are $62.0 \%$ for $\mathrm{Cu} / \mathrm{Fe}$ particles, $19.5 \%$ for zero-valent copper nano-particles, and $18.1 \%$ for zero-valent iron nano-particles. Additionally, a substance with higher dielectric loss is more capable of absorbing MW energy and converting it into heat energy. The order of magnitude for dielectric loss is nano-scale $\mathrm{Fe}^{0}(38.2)>\mathrm{Cu} / \mathrm{Fe}$ (30) $>$ nano-scale $\mathrm{Cu}^{0}$ (9.7) that indicates the order of magnitude of the capacity in absorbing and converting MW energy being nano-scale $\mathrm{Fe}^{0}>\mathrm{Cu} / \mathrm{Fe}>$ nano-scale $\mathrm{Cu}^{0}$. Laboratory results confirm that under similar $\mathrm{MW}$ irradiation (i.e. 250-W MW for $300 \mathrm{sec}$ ), $\mathrm{Cu} / \mathrm{Fe}$ has better $\mathrm{CB}$ removal rate that either $\mathrm{Fe}^{0}$ or $\mathrm{Cu}^{0}$ indicating that the copper added to $\mathrm{Fe}^{0}$ plays the role of catalyst to result in better treatment efficiency for the bi-metal $\mathrm{Cu} / \mathrm{Fe}$ particles. The ultimate $\mathrm{CB}$ removal efficiencies are $82.8 \%$ for $\mathrm{Fe}^{0}$ nano-particles $76.2 \%$ for $\mathrm{Cu} / \mathrm{Fe}$ nano-particles, and $72.1 \%$ 
for $\mathrm{Cu}^{0}$ nano-particles.

\section{References}

Al-Harahsheh, M., Kingman, S., \& Bradshaw, S. (2006). The reality of non-thermal effects in microwave assisted leaching systems. Hydrometallurgy, 84, 1-13. http://dx.doi.org/10.1016/j.hydromet.2006.03.056

Appleton, T. J., Colder, R. I., Kingman, S. W., Lowndes, I. S., \& Read, A. G. (2005). Microwave technology for energy-efficient processing of waste. Applied Energy, 81, 85-113. http://dx.doi.org/10.1016/j.apenergy.2004.07.002

Bilbao-Sáinz, C., Butler, M., Weaver, T., \& Bent, J. (2007). Wheat starch gelatinization under microwave irradiation and conduction heating. Carbohydrate polymers, 69, 224-232. http://dx.doi.org/10.1016/j.carbpol.2006.09.026

Cheng, S. F., \& Wu, S. C. (2000). The enhancement methods for the degradation of TCE by zero-valent metals. Chemosphere, 41, 1263-1270. http://dx.doi.org/10.1016/S0045-6535(99)00530-5

Clark II, C. J., Rao, P. S. C., \& Annable, M. D. (2003). Degradation of perchloroethylene in cosolvent solutions by zero-valent iron. Journal of Hazardous Materials, 96, 65-78. http://dx.doi.org/10.1016/S0304-3894(02)00162-0

Hidaka, H., Saitou, A., Honjou, H., Hosoda, K., Moriya, M., \& Serpone, N. (2007). Microwave-assisted dechlorination of polychlorobenzenes by hypophosphite anions in aqueous alkaline media in the presence of Pd-loaded active carbon. Journal of Hazardous Materials, 148, 22-28. http://dx.doi.org/10.1016/j.jhazmat.2007.01.143

Horikoshi, S., \& Serpone, N. (2009). Photochemistry with microwaves: catalysts and environmental applications. Journal of Photochemistry and Photobiology C: Photochemistry Reviews 10, 96-110. http://dx.doi.org/10.1016/j.jphotochemrev.2009.06.001

Janda, V., Vasek, P., Bizova, J., \& Belohlav, Z. (2004). Kinetic models for volatile chlorinated hydrocarbons removal by zero-valent iron. Chemosphere, 54, 917-925. http://dx.doi.org/10.1016/j.chemosphere.2003.08.033

Jones, D. A., Lelyveld, T. P., Mavrofidis, S. D., Kingman, S. W., \& Miles, N. J. (2002). Microwave heating applications in environmental engineering-a review. Resources, Conservation and Recycling, 34, 75-90. http://dx.doi.org/10.1016/S0921-3449(01)00088-X

Jou, C. J. (2008). Degradation of pentachlorophenol with zero valence iron coupled with microwave energy. Journal of Hazardous Materials, 52, 699-702. http://dx.doi.org/10.1016/j.jhazmat.2007.07.036

Jou, C. J., \& Wu, C. R. (2008). Granular activated carbon coupled with microwave energy for treating pentachlorophenol-containing wastewater. Environmental Progress, 27, 111-116. http://dx.doi.org/10.1002/ep.10245

Jou, C. J. G., Lee, C. L., Lin, C., \& Huang, H. W. (2010a). Combining zero-valent iron nanoparticles with microwave energy to treat chlorobenzene. Journal of the Taiwan Institute of Chemical Engineers, 41, 216-220. http://dx.doi.org/10.1016/j.jtice.2009.08.012

Jou, C. J. G., Wu, C. R., \& Lee, C. L. (2010b). Application of microwave radiation to treat granular activated carbon contaminated with chlorobenzene. Environmental Progress, 29, 272-277. http://dx.doi.org/10.1002/ep.10400

Jou, C. J. G., Lee, C. L., Tsai, C. H., \& Wang, H. P. (2008). Microwave energy enhanced photocatalyses with titanium dioxide $\left(\mathrm{TiO}_{2}\right)$ for degradation of trichloroethylene. Environmental Engineering Science, 25, 975-980. http://dx.doi.org/10.1089/ees.2007.0155

Lee, H. Y., Lee, C. L., \& Jou, C. J. G. (2010a). Comparison degradation of pentachlorophenol using microwave-induced nanoscale $\mathrm{Fe}^{0}$ and activated carbon. Water, Air, \& Soil Pollution, 211, 17-24. http://dx.doi.org/10.1007/s11270-009-0276-5

Lee, C. L., Jou, C. J. G., \& Huang, H. W. (2009b). Degradation of chlorobenzene in water using nano-scale Cu coupled with microwave irradiation. ASCE's Journal of Environmental Engineering, 136, 412-416. http://dx.doi.org/10.1061/(ASCE)EE.1943-7870.0000163

Lee, C. L., Jou, C. J. G., \& Wang, H. P. (2010b). Enhance degradation of chlorobenzene in aqueous solution using microwave-induced zerovalent iron and copper particles. Water Environmental Research, 82, 642-647. 
http://dx.doi.org/10.2175/106143009X12529484816033

Lien, H. L., \& Zhang, W. X. (2007). Nanoscale Pd/Fe bimetallic particles: Catalytic effects of palladium on $\begin{array}{lllll}\text { hydrodechlorination. Applied Catalysis } \quad \text { B: } & \text { Environmental, 77, 110-116. }\end{array}$ http://dx.doi.org/10.1016/j.apcatb.2007.07.014

Lin, C. J., \& Lo, S. L. (2005). Effects of iron surface pretreatment on sorption and reduction kinetics of trichloroethylene in a closed batch system. Water Research, 39, 1037-1046. http://dx.doi.org/10.1016/j.watres.2004.06.035

Lin, C. J., Lo, S. L., \& Liou, Y. H. (2004). Dechlorination of trichloroethylene in aqueous solution by noble metal-modified iron. Journal of Hazardous Materials, B116, 219-228. http://dx.doi.org/10.1016/j.jhazmat.2004.09.005

Liu, X., Quan, X., Bo, L., Chen, S., \& Zhao, Y., (2004). Simultaneous pentachlorophenol decomposition and granular activated carbon regeneration assisted by microwave irradiation. Carbon, 42, 415-422. http://dx.doi.org/10.1016/j.carbon.2003.12.032

Lien, H. L., \& Zhang, W. X. (2001). Nanoscale iron particles for complete reduction of chlorinated ethenes. Colloids and Surfaces A: Physicochemical and Engineering Aspects, 191, 97-105. http://dx.doi.org/10.1016/S0927-7757(01)00767-1

Liou, Y. H., Lo, S. L., Lin, C. J., Kuan, W. H., \& Weng, S. C. (2005). Chemical reduction of an unbuffered nitrate solution using catalyzed and uncatalyzed nanoscale iron particles. Journal of Hazardous Materials B, 127, 102-110. http://dx.doi.org/10.1016/j.jhazmat.2005.06.029

Menéndez, J. A., Inguanzo, M., \& Pis, J. J. (2002). Microwave-induced pyrolysis of sewage sludge. Water Research, 36, 3261-3264. http://dx.doi.org/10.1016/S0043-1354(02)00017-9

Park, M., Komarneni, S., \& Roy, R. (2000). Microwave-hydrothermal decomposition of chlorinated organic compounds. Materials Letters, 43, 259-263. http://dx.doi.org/10.1016/S0167-577X(99)00270-0

Parida, K. M., \& Parija, S. (2006). Photocatalytic degradation of phenol under solar radiation using microwave irradiated zinc oxide. Solar Energy, 80, 1048-1054. http://dx.doi.org/10.1016/j.solener.2005.04.025

Su, C., \& Puls, A. W. (1999). Kinetics of trichloroethene reduction by zero valent iron and Tin: pretreatment effect, apparent activation energy, and intermediate products. Environmental Science Technology, 33, 163-168. http://dx.doi.org/10.1021/es980481a

Takashima, H., Karches, M., \& Kanno, Y. (2008). Catalytic decomposition of trichloroethylene over Pt-/Ni-catalyst under microwave heating. Applied Surface Science, 254, 2023-2030. http://dx.doi.org/10.1016/j.apsusc.2007.08.030

Xu, X., Zhou, M., He, P., \& Hao, Z. (2005b). Catalytic reduction of chlorinated and recalcitrant compounds in $\begin{array}{llllll}\text { contaminated water. Journal of Hazardous Materials } & \text { B, } & \text { 123, } & \text { 89-93. }\end{array}$ http://dx.doi.org/10.1016/j.jhazmat.2005.04.002

Xu, X., Zhou, H., He, P., \& Wang, D. (2005a). Catalytic dechlorination kinetics of p-dichlorobenzene over Pd/Fe catalysts. Chemosphere, 58, 1135-1140. http://dx.doi.org/10.1016/j.chemosphere.2004.07.010

Xu, X., Zhou, H., \& Zhou, M. (2006). Catalytic amination and dechlorination of para-nitrochlorobenzene (p-NCB) in water over palladium-iron bimetallic catalyst. Chemosphere, 62, 847-852. http://dx.doi.org/10.1016/j.chemosphere.2005.04.073

Yuan, S., Tian, M., \& Lu, X. (2006). Microwave remediation of soil contaminated with hexachlorobenzene. Journal of Hazardous Materials B, 137, 878-885. http://dx.doi.org/10.1016/j.jhazmat.2006.03.005

Zhang, W. X., Wang, C. B., \& Lien, H. L. (1998). Treatment of chlorinated organic contaminants with nanoscale bimetallic particles. Catalysis Today, 40, 387-395. http://dx.doi.org/10.1016/S0920-5861(98)00067-4

Zhang, Z., Shan, Y., Wang, J., Ling, H., Zang, S., Gao, W., Zhao, Z., \& Zhang, H. (2007). Investigation on the rapid degradation of congo red catalyzed by activated carbon powder under microwave irradiation. Journal of Hazardous Materials, 147, 325-333. http://dx.doi.org/10.1016/j.jhazmat.2006.12.083 